\title{
Pedagogical strategies for Chemical Engineering courses: Skills development through Project-based learning (PBL)
}

\author{
Estratégias pedagógicas para os cursos de Engenharia Química: Desenvolvimento de competências \\ por meio da aprendizagem baseada em projetos (ABP) \\ Estrategias pedagógicas para los cursos de Ingeniería Química: Desarollo de habilidades através \\ del aprendizaje basado em projectos (ABP)
}

Received: 04/27/2021 | Reviewed: 05/03/2021 | Accept: 06/13/2021 | Published: 06/26/2021

Fernanda Ribeiro dos Santos

ORCID: https://orcid.org/0000-0001-5281-7109 Universidade Federal de Minas Gerais, Brazil

E-mail: fernandaribeirods@ hotmail.com

Idalmo Montenegro de Oliveira

ORCID: https://orcid.org/0000-0002-8792-6943

Universidade Federal de Minas Gerais, Brazil E-mail: idalmo@ufmg.br

Luiz Carlos Santos

ORCID: https://orcid.org/0000-0002-8646-5946

Universidade Federal de Minas Gerais, Brazil E-mail: luizcs@deq.ufmg.br

Rafaela Esteves Godinho Leal

ORCID: https://orcid.org/0000-0002-1410-6645

Universidade Federal de Minas Gerais, Brazil

E-mail: rafaelagodinholeal@gmail.com

Marcelo Cardoso

ORCID: https://orcid.org/0000-0001-8345-8890

Universidade Federal de Minas Gerais, Brazil E-mail: mcardoso@deq.ufmg.br

\begin{abstract}
The formal curriculum practices in engineering education have been rethought in order to meet the growing demand for the development of the more traditional skills, as well as newer multidisciplinary skills for the students, making them protagonists in their own development and forging the curriculum through concrete activities (curriculum in action) that go beyond the prescribed curriculum. As a fundamental part of this process, a project was developed by students and professors of the Chemical Engineering course, where the Project-Based Learning methodology was applied. During the traditional curriculum course "Operations and Processes Laboratory", students were able to work with the curriculum in action through four main activities that required the application of technical knowledge linked to communication skills and problem solving, adaptation to reality, proactivity and analytical ability. The development of competences and skills by the students was analyzed based on the reports they presented as a result of their group projects and summarized in a matrix of general engineering competences, based on the Brazilian National Curriculum Guidelines. Through this matrix it was possible to conclude that the students solved the real problem situations using the technical knowledge learned at the University, while taking into account the relevant economic, environmental and social aspects. They defined the theme of their work, goals and the methodology to be developed with complete autonomy. They exercised creativity and used multidisciplinary skills to seek solutions and adapt resources, acquiring equipment and supplies, developing and building adaptively, while utilizing the tools at their disposal. They exercised the analytical capacity to elucidate the results and present improvements and also introduced digital technologies to facilitate communication and other processes.
\end{abstract}

Keywords: Professional skills; Project-based learning methodology; Kraft Process; Filter prototype.

\section{Resumo}

As práticas curriculares formais do ensino de engenharia vem sendo repensadas no intuito de atender a demanda crescente pelo desenvolvimento de competências e novas habilidades multidisciplinares dos alunos, tornando-os protagonistas pelo próprio desenvolvimento e forjando o currículo em ação, que vai além do currículo prescrito. Nesse sentido, um projeto foi desenvolvido por discentes e docentes do curso de Engenharia Química, cuja metodologia Aprendizagem Baseada em Projetos foi aplicada. Durante a disciplina curricular "Laboratório de Operações e Processos" os alunos puderam trabalhar com o currículo em ação a partir de quarto atividades principais que fizessem 
necessárias a aplicação do conhecimento técnico atrelado a habilidade de comunicação e resolução de problemas, adaptação a realidade, proatividade e capacidade analítica. O desenvolvimento de competências e habilidades pelos estudantes foi analisado a partir dos relatórios apresentados por eles como resultado de seus projetos em grupo e sumarizados em uma matriz de competências gerais do engenheiro, baseada nas Diretrizes Curriculares Nacionais brasileiras. Por meio dessa matriz foi possível concluir que os alunos resolveram as situações-problema reais utilizando o conhecimento técnico aprendido na Universidade, considerando os aspectos econômicos, ambientais e sociais. Definiram o tema de seus trabalhos, metas e a metodologia a ser desenvolvida com total autonomia. Utilizaram a criatividade e a multidisciplinaridade para buscar soluções e adaptar os recursos, adquirindo equipamentos e insumos, construindo e adaptando com as ferramentas que estavam à disposição. Exerceram a capacidade analítica para elucidar os resultados e apresentar melhorias e também inseriram as tecnologias digitais para facilitar a comunicação e processos.

Palavras-chave: Competências profissionais; Metodologia de aprendizagem baseada em projetos; Processo Kraft; Protótipo de filtro.

\section{Resumen}

Las prácticas curriculares formales en la enseñanza de la ingeniería se han replanteado para satisfacer la creciente demanda de desarrollo de habilidades y nuevas habilidades multidisciplinarias de los estudiantes, haciéndolos protagonistas de su propio desarrollo y forjando el currículo en acción, que va más allá del currículo prescrito. En este sentido, se desarrolló un proyecto por parte de estudiantes y profesores de la carrera de Ingeniería Química, cuya metodología de Aprendizaje Basado en Proyectos se aplicó. Durante la asignatura curricular "Laboratorio de Operaciones y Procesos", los alumnos pudieron trabajar con el currículo en acción a partir de cuatro actividades principales que requerían la aplicación de conocimientos técnicos vinculados a las habilidades comunicativas y de resolución de problemas, la adaptación a la realidad, la proactividad y la capacidad analítica. El desarrollo de competencias y habilidades de los estudiantes fue analizado a partir de los informes presentados por ellos como resultado de sus proyectos grupales y resumidos en una matriz de competencias generales de ingeniería, con base en las Directrices Curriculares Nacionales de Brasil. A través de esta matriz se pudo concluir que los estudiantes resolvieron las situaciones problemáticas reales utilizando los conocimientos técnicos adquiridos en la Universidad, considerando los aspectos económicos, ambientales y sociales. Definieron la temática de su trabajo, metas y la metodología a desarrollar con total autonomía. Utilizaron la creatividad y la multidisciplinariedad para buscar soluciones y adaptar recursos, adquiriendo equipos e insumos, construyendo y adaptándose con las herramientas a su disposición. Ejercieron la capacidad analítica para dilucidar los resultados y presentar mejoras, y también introdujeron tecnologías digitales para facilitar la comunicación y los procesos.

Palabras clave: Competencias profesionales; Metodología de aprendizaje basada en proyectos; Proceso Kraft; Prototipo de filtro.

\section{Introduction}

Every society that reaches a certain degree of maturity becomes aware of the need to provide its members with education. This is the principle by which human communities continuously preserve and transfers their habits, customs, skills, values, and knowledge, that is, their physical and cultural peculiarities, among other things, first of all, education is not only an individual possession, but is essentially linked to the larger society to which they belong (Jaeger, 1986).

Society has evolved and changed significantly over time. In ancient times, engineers, so well depicted in Egyptian and Hellenistic societies as being responsible for important constructions, were surprisingly absent from formal higher education (Marrou, 1981). It was they, certainly, who could have exercised the practice of arithmetic or geometric calculus.

However, we do not see that there were, strictly speaking, higher educational institutions where these subjects actually had been taught. The exact sciences themselves were, in fact, relegated to marginal courses, which sometimes were optional. Civil and mechanical construction were unworthy of doctors, and it goes without saying that these instructors never had citizenship rights in medieval universities; the architects and the first engineers, who appeared in the 14th century, were trained outside of these halls. At that time, education was focused only on a small part of society, normally nobles, intellectuals and philosophers (Charle \& Verger, 2007).

After the Industrial Revolution, education began to be recognized as a right of every citizen and therefore it became necessary to create a new system. The world was going through a drastic transformation process, requiring new schools, capable of introducing technical and professional education, in order to guarantee qualified labor to facilitate the growth of 
industry. The first school dedicated to formal engineering education and organized with the kind of characteristics that most resemble modern institutions was the École Nationale des Ponts et Chaussées (ENPC), founded in 1747 in France (Charle \& Verger, 2007). It was centered on a single teacher who was responsible for teaching dozens of students at the same time and who introduced the same techniques and characteristics practiced in industrial production: repetitive and mechanical tasks.

Following the Second World War, societies underwent a series of important transformations linked mainly to technological evolutions. This is referred to as the technoscientific revolution, and the changes wrought went far beyond mere industrial transformations, whose main advances were linked to the creation of computers, electronic circuits, software, robots, cell phones, and chips, among others. The management hierarchy system and the so-called production lines were replaced by multi-skilled teams working together, with the potential to significantly reduce human efforts and costs. These new technologies and the increasing velocity of information changed people's thinking and lifestyles, which profoundly altered the characteristics typical of 21 st century society. In today's society, rules and values no longer have the same rigidity that they did in the past (Castells, 2009; Mosé, 2013). In this context, the relationship between the student and information has been fundamentally altered, giving rise to the notion of student protagonism, which opens a path for change in the current educational paradigm. In this scenario, the student begins to take charge of his own learning process, allowing him to participate in projects that really arouse his interest and strengthen his training. This breaks the vertical hierarchy of teaching in favor of horizontality, creating an opportunity for knowledge to be built collectively. In addition, we live in a time of digital media, which is characterized by information that is produced, and communicated without mediators (Han, 2017). This allows students to become autonomous and co-responsible for their own development which has ushered in a new era of learning based on innovation and the foundation of the focus on the development of students' skills.

It is possible to observe, historically, in Engineering curricula, from their origin until today, that most continue to conform to a curricular structure distributed in disciplines from the basic cycle to the specific cycle of each Engineering course, with fragmented and decontextualized contents. This teaching is transmitted to students passively, from classes that use verbal language and abstract reasoning to build deductive and sequential knowledge. The classes are mostly expository and laboratory practices that are the result of the replication of traditional practices by teachers. These, who first were also students themselves and did not undergo specific training for teaching but later learned to teach with their own practice, hardly dedicate themselves to reflection and critical analysis on the adequacy of content and methods to the current globalized and connected context (Belisário, et al., 2020). It is the view of this report that there is a need for a way to restructure merely content-centric, fragmented teaching, isolated from the context, to achieve an education centered on the development of skills and creativity.

Given this objective, it becomes possible to perceive the need to reformulate curricular practices in engineering education beyond the notion of a prescribed curriculum. According to Sacristán (2017), it does not make sense to renew the contents without changes in procedures and a wide discussion of a more holistic view of teaching and learning. It is important for everyone to understand that the complete curriculum goes far beyond the prescribed curriculum itself, that which serves as a reference in the ordering of the curriculum system, which serves as a starting point for defining the contents and preparing materials, among other things. Additionally, according to Sacristán (2017), the value of the curriculum is proven in the way it is carried out in educational practice. For the author, the "curriculum in action is the ultimate expression of its value, because, in short, it is in practice that every project, every idea, every intention, becomes reality in one way or another; it manifests itself, acquires meaning and value, regardless of declarations and purposes of departure" (Sacristán, 2017). Thus, the educational practice is composed of actions and pedagogical strategies that forge the curriculum in action.

Knowledge needs to be built and for that to happen, methods must be created to stimulate this construction, according to the learning theory developed by the Swiss psychologist Jean Piaget in the early 1920s. This construction must happen through the mediating teacher and the students themselves, that they are not just mere learners, but that: the student is the 
center and the protagonist of the learning process; the level of maturity of each student is respected; the process is dynamic, built gradually, and each new knowledge is learned from previous concepts (Markham, et al., 2003).

When formal education also focuses on skills, it is valuing not only content that in the contemporary world can often quickly become obsolete, but the ability to face a problem situation that is, in a way, linked to one's ability to think and create. For Gómes (2011), competences "constitute a complex and adaptive 'know-how', that is, knowledge that is applied not mechanically, but reflexively, capable of adapting to a diversity of contexts and has integrative character, encompassing knowledge, skills, emotions, values and attitudes." In this sense, new skills derive from acquired skills, from "knowing how to do". Therefore, training aimed at developing skills requires different pedagogical strategies in the curriculum of a course and calls for other roles for teachers and students.

The process of training the engineer is challenging in today's world, where the acquisition of knowledge is growing, complex and changeable, in parallel with the development of professional attributes that necessarily pass through differentiated and alternative methods to facilitate this training. In this context, the most appropriate methodology used in the training of these professionals is Project-Based Learning, abbreviated as PBL, which is recognized as offering students a means of acquiring knowledge and developing valued skills and attitudes, according to Ribeiro \& Mizukami (2005). The development of project-based learning methodology had its origins in the early 1900s, when the American philosopher John Dewey (18591952) proved "learning through doing", valuing, questioning and contextualizing students' ability to think in a constructivist way.

Engineering courses, in many well-known institutions, often value the transmission of content, discrediting teachinglearning strategies that aim to develop skills and competencies for problem solving. In order to meet the needs of society and work on the curriculum in action, in this work we will present and discuss a project that aims to apply some pedagogical practices that provide improvements in learning without compromising the existing content. To this end, a group of students and teachers was created with the purpose of working with the curriculum in action through educational practices, based on real problem situations that make it necessary to apply technical knowledge linked to the ability to communicate and solve problems, adapt to reality, react proactivity and improve the analytical skills of students, characteristics that are essential for professionals in the 21 st century.

Therefore, the objective of this paper is to present a work developed from the "project-based learning" methodology involving a team, formed by undergraduate students, enrolled in the Process Operations Laboratory (LOP) class of the Chemical Engineering course at the Federal University of Minas Gerais, with the active participation of a graduate student, three professors from the course, a pedagogue from the institution and professional engineers from the industrial area. The project was developed in order to foster the development of professional skills and competences, through: autonomy, collaborative activities and the use of virtual social networks in interactions and communication between people. Based on the objective of this article, the materials and methods applied in this work are presented below.

\section{Methodology}

\subsection{Pedagogical strategies in the Unit Operations Laboratory: Project Based Learning methodology}

Project Based Learning, known as PBL (Problem Based Learning), originates with the pedagogy of the American philosopher Jonh Dewey, who is considered to be one of the founders of methodological pragmatism. Dewey developed a pedagogy centered on experience. For the philosopher, there is an active exchange between the subject and nature and both are transformed in this process. For Dewey, to man, the control of experience is reliable through the scientific method and the principles of experimentation, generalization, hypothesis and verification. Thus, his thinking was linked to industrialization, science and democracy (Cambi, 1999). 
Dewey's pedagogy is characterized by the centrality of the "doing" of the student, envisioning a constant articulation between theory and practice, which made him an advisor of the "active school", a movement that started in the 19th century and continues to present times in Europe and America. For Dewey, there must be a centrality in the student as the protagonist of the teaching-learning process. Dewey defended the creation of laboratories in order to link academic activities with productive ones. He understood that the school should open up to the community and that the teacher would assume the role of a guide that regulates students' research activities (Cambi, 1999).

This "Project Based Learning" methodology was developed in three years (2018 to 2020) within the confines of the Laboratory of Operations and Processes (LOP) program course. Four distinct groups of students were involved who, motivated by problems, necessities, opportunities and challenges in the industry, were part of the global project "Evaluation of the Stages of the Production Process of an Industrial Plant”. Each semester, a group from the LOP class developed a different and independent project within the scope of the overall theme, accompanied by a graduate student in Chemical Engineering, a group of professors, a pedagogue from the institution and professional engineers from the industrial area. The teaching team was composed of three teachers from different backgrounds: A coordinator with extensive experience in the process area, having worked in consultancy in several industries; another professor specialized in the process to be analyzed and finally; a professor with experience in the field of industrial designs in CAD and 3D printing. The pedagogue is part of the University's Directorate of Innovation and Teaching Methodologies, and in the group, she is responsible for monitoring discussions about the course, suggests books and articles in the area of education and sets goals with the team for the implementation of educational practices. The participating professional engineers work in industrial areas of the themes related to the project as well as in customer support, and are in constant contact with the requirements and demands from each area. In addition, they provide all the necessary technical support for the project, providing samples of raw materials, analysis and industrial information. The graduate student also develops her research in the area of the project, contributing to the direction of work and supervision. The role of each of these professionals involved becomes essential, since all of the work is oriented, conducted and carried out through discussions and decision making in a network format. It is, therefore, an interdisciplinary teaching practice, involving the area of processes, industrial designs, digital technologies, industry and the production process.

The LOP is a class in the last year of the curriculum of the Chemical Engineering course, a course that is usually completed in 5 years by students, and aims to integrate theoretical and practical knowledge acquired in various sub-areas of knowledge, through the experimental development of an industrial process on a laboratory scale or computer simulation. The objective of this discipline is to explore the concepts of scientific methodology, from production and participation in a project. Students go through all the stages of a scientific work: reviewing the literature, defining the methodology to be adopted, carrying out experiments or simulation, analyzing the results and preparing a final report. They work on the solution of several common problems in the industry or in research project, and they need to position themselves, go deeper into detail and propose solutions related to them. This process, without a doubt, provides for greater exchange between the School and the students with industry. In addition, the objective is also to prepare them for the job market, developing skills from practical experience.

At the beginning of the semester, the class of approximately 30 students, is divided into groups averaging about 5 students. The supervising professors from several sub-areas within the Chemical Engineering course present their pre-projects and work proposals through seminars after which there is a debate between students and teachers about the proposals presented and any resulting questions. The groups then define among themselves the choice of a theme to be developed and a respective group of advisors. Subject to the PBL methodology and under the guidance of the teachers who authored this article, they start the development of each project independently. 
Students have the autonomy to ask questions about the topic and make a project proposal. This proposal is presented to supervisors and graduate students who will make suggestions based on industrial experience and previous projects. From that moment on, students actually start their projects, identifying and sourcing the resources that are available in the University's laboratory, as well as those that will need to be acquired or modified. The objective is for them to mobilize to source the materials and equipment they will need. They may be able find these tools in other laboratories at the University itself, or if unsuccessful, they have two options for resolving the problem: acquire using the resources of the laboratory itself or design and build parts and equipment using existing materials.

Considering the limited resources for the acquisition of products or equipment with high added value, priority is given to the utilization of the resources present in the laboratory and to collaborative work in partnership with other laboratories at the University, stimulating the development of the students' adaptive and creative skills.

In the pilot program, the evolution of the projects was monitored through weekly meetings. In the first projects, all meetings were held face-to-face at the Industrial Processes Laboratory. Due to the corona virus pandemic (COVID-19), the last group's activities were all conducted remotely using videoconferencing platforms (Microsoft Teams, Google Meet and Hangouts). In all projects, a user-group was maintained on the WhatsApp platform for discussing questions and suggestions throughout the development and for sharing information among all members. Observations were evaluated by everyone in a dynamic and horizontal fashion.

At the end of the program, each group wrote a report that was presented to the supervisors and the graduate student, who recommended changes to be made in the final text. After the changes, an appraisal panel was appointed, composed in large part by the advisers and representatives from the lime-mining industry. The works were evaluated based on the students' presentation, the final report and the students' arguments in response to the questions raised by the board. Any new suggestions by the board were incorporated in the report to be registered at the University. These final reports were used in this article as a basis for analyzing the development of skills by students.

\subsection{Methodological procedures}

Qualitative research was conducted in order to analyze the application of the PBL methodology in the Unit Laboratories class (LOP) regarding the development of the engineer's professional skills and abilities. This research "[was] not concerned with numerical representativeness, but, yes, with the deepening of the understanding of a social group, an organization, etc." (Gerhardt \& Silveira, 2009). Its purpose was, therefore, to understand the development of skills by students through prescriptive research with documentary analysis. The final reports developed in the LOP class between the years 2018 and 2020 were analyzed. The projects analyzed below were carried out under the specific supervision of the teachers who wrote this article. 
Table 1 - Themes developed in LOP student's projects

\begin{tabular}{|c|c|c|c|c|}
\hline Project & Title & Objective & Year & $\begin{array}{l}\text { Number of } \\
\text { students } \\
\text { involved }\end{array}$ \\
\hline A & $\begin{array}{l}\text { "Influence of } \\
\text { granulometry and } \\
\text { silica content of } \\
\text { quicklime in the } \\
\text { Kraft pulp } \\
\text { production process" }\end{array}$ & $\begin{array}{l}\text { "The present work has as a general objective the study of the } \\
\text { effects of granulometry and the silica content of lime in the pulp } \\
\text { mill. The study will make it possible to understand the Kraft } \\
\text { process and the impacts of lime quality on its processing, in } \\
\text { addition, it is expected to identify points of performance } \\
\text { improvement in the process." (Júnior, et al., 2018). }\end{array}$ & 2018 & 4 \\
\hline B & $\begin{array}{l}\text { "Preliminary } \\
\text { analysis of the } \\
\text { filterability tests of } \\
\text { white liquor from } \\
\text { different limes in the } \\
\text { pulp mill" }\end{array}$ & $\begin{array}{l}\text { "The present work proposes, as a general objective, the study of } \\
\text { the effects of common lime contaminants on the filterability of } \\
\text { white liquor in the lime recovery cycle in the pulp mill. The } \\
\text { main contaminants evaluated are silicon, magnesium and } \\
\text { aluminum oxides." (Camilo \& Araújo, 2019). }\end{array}$ & 2019 & 2 \\
\hline $\mathrm{C}$ & $\begin{array}{l}\text { "Analysis of the } \\
\text { causticizing process } \\
\text { from different } \\
\text { samples of limes" }\end{array}$ & $\begin{array}{l}\text { "The present work proposes, as a general objective, to evaluate } \\
\text { the performance of new limes during the hydration and } \\
\text { causticizing processes in green liquor from the pulp mill." } \\
\text { (Rettore, et al., 2019). }\end{array}$ & 2019 & 4 \\
\hline $\mathrm{D}$ & $\begin{array}{l}\text { "Prototyping and } \\
\text { performance } \\
\text { evaluation of a Leaf } \\
\text { test filter" }\end{array}$ & $\begin{array}{l}\text { "The objective of this work is to develop and validate a } \\
\text { prototype filter for the separation of white liquor and calcium } \\
\text { carbonate }\left(\mathrm{CaCO}_{3}\right) \text {, aiming to reproduce this stage of the pulp } \\
\text { industry's Kraft process in the laboratory." (França, et al., 2020). }\end{array}$ & 2020 & 5 \\
\hline
\end{tabular}

Source: Authors.

As an initial step, an analysis matrix of the competencies of the engineer was created based on the National Curricular Guidelines (DCN, 2019). The following general skills of the engineer were listed:

- Holistic and humanistic vision;

-Technical degree/training;

- Incorporation of digital technologies;

- Interdisciplinarity and multidisciplinary approach;

- Engineering problem-solving;

- Ability for evaluation.

Then, the final reports were analyzed in order to verify the skills potentially acquired by students in the development of each project, they are:

a) Holistic and humanistic vision

Based on the objectives and justification, it was possible to identify the problem situation developed by the students in each project. In reproducing this problem, students were evaluated based upon their ability to recognize users' needs in a comprehensive fashion when formulating the engineering problem, considering relevant economic, social, cultural and environmental aspects.

b) Technical degree \& training

From the problem situation, students were able to propose the experimentation method for generating real results, analyzing and understanding the physical and chemical phenomena involved. In order to do this, mathematical, statistical and computational tools needed to for verifying and validating the data in an appropriate way. 
c) Applied digital technologies

Students used available technology tools for researching, developing and adapting projects. The use of technology in communication was intended to facilitate and make it more efficient and dynamic, fostering the exchange of information and network collaboration.

d) Multidisciplinarity and interdisciplinarity approach

The students worked as part of a proactive and collaborative team, combining knowledge from various disciplines in the development of their projects.

e) Solving engineering problems

The students were expected to be able to conceive, design and analyze systems, products and processes, understanding the context and devising creative, desirable and viable solutions (technically and economically) applying the use of appropriate techniques.

\section{f) Evaluative Capacity}

Ability to evaluate the completed projects and consider the problems identified to propose solutions applicable to future projects. In the chemical industry there are similar steps that involve physical and chemical principles, regardless of the specific problem of each project developed and the material being manufactured by each group of students. All groups of students had to go through these stages, which are essential to the mobilization of the technical knowledge of Chemical Engineering. The next section presents these stages carried out in the projects.

\subsection{Activities carried out in the projects: technical application}

Each chemical process corresponds to a specific set of interconnected equipment, utilized for transforming a raw material into a product of interest, safely and on a commercial scale. Irrespective of the specific chemical industry, similar steps will be taken, involving physical and chemical principles, regardless of the material being manufactured. The main element in the production of a chemical product, in general, is the chemical reactor, where the transformation of raw materials into products and byproducts takes place. Several transformations in the material can occur in the equipment utilized just before and right after the reactor involving: heat transfer, agitation and mixing, separation processes, as well as others.

These separation processes include: Physical processes in which the separation of two phases (solid-liquid and liquidliquid) is allowed, such as filtration; Processes in which mass transfers occur from one phase to another due to the material's affinity for the second phase, such as absorption or adsorption or due to the effect of heat transfer, such as evaporation and distillation.

This report will analyze the development and preparation of a reactor to be utilized in laboratory reproduction of the slaking and causticizing reactions of lime. The first reaction is highly exothermic. Both are reactions essential in the recovery process for chemical compounds, which is one of the stages of the Kraft pulp production process. This process occurs by pulping wood using sodium hydroxide $(\mathrm{NaOH})$ and sodium sulfide $\left(\mathrm{Na}_{2} \mathrm{~S}\right)$, separating the cellulose fibers. The purpose of the slaking and causticizing of lime, then, is to recover these chemical compounds, restarting the production cycle.

The solid-liquid separation process for the byproducts of the lime causticizing reaction, utilizing immersion filtration, will also be analyzed. This process is needed to reduce the recirculation of inert or harmful compounds into the process which affects the efficiency of the equipment and reactions. It is important to note that the preparation of the reactor and the 
development of a filtration prototype were developed specifically for this process. However, the methodology used may be similar to other chemical processes that involve chemical reactions or a filtration separation process.

The development of the projects was carried out by four different groups of students from the LOP class, corresponding to four different semesters from the development of projects, which we will refer to as: project A, project B, project $\mathrm{C}$ and project $\mathrm{D}$. Next, we will present the four main general activities developed by these different groups of students, which are:

\section{- Activity 1 - Preparation of the thermal insulation for a batch chemical reactor}

The reactor used was a stainless-steel jacketing model, with physical dimensions of $15 \mathrm{~cm}$ height and an $8 \mathrm{~cm}$ internal diameter. In order to improve the thermal insulation of this metallic reactor, insulation materials were chosen that are easy to acquire, inexpensive and have a low thermal conductivity value (0.020 to $0.040 \mathrm{~W} / \mathrm{mK}$ ) (Perry \& Green, 1999). Since it would not be used, the reactor jacket was initially sealed. First, the reactor was surrounded by a thick layer of rock wool and, just beyond and covering that, a layer of thermal blanket affixed with electrical tape. The reactor was placed in a plastic container that was covered on the bottom and the sides with Styrofoam and was set with expansive polyurethane foam.

\section{- Activity 2 - Monitoring the reaction temperature over time (reactivity)}

In order to automate the monitoring of the reaction temperature, a system was implemented using Arduino Uno. A temperature sensor (thermocouple) was inserted into the reactor cover and connected to the Arduino Uno prototyping platform. This allowed for the temperature measurement to be transmitted in real time to the computer it was connected to. Thus, it was possible to plot the temperature as a function of the reaction time and to find the profiles (reactivity) of each analyzed lime sample.

The Arduino consists of a low-cost, open-source electronic prototyping platform that can, by means of coupled sensors, measure and control properties present in the environment when it is paired to a computer. This is done via a micro controller present on the board that can be programmed using the $\mathrm{C} / \mathrm{C}++$ programming language. Among the advantages of utilizing this system are its ease and flexibility of use.

\section{- Activity 3 - Carrying out the experimental tests between lime and water or green liquor}

The lime samples (calcium oxides) used were supplied by a limestone mining industry. Mother samples were taken and subsequently homogenized. From these, lime samples of different granulometric bands were selected for evaluating this parameter. The effect of chemical composition was also analyzed when analyzing more than one mother sample. Experiments of lime with water (slaking) and lime with green liquor (causticizing) were carried out. Samples of clarified green liquor (a solution composed of sodium sulfide and sodium carbonate) were provided by a pulp mill.

For each experiment, $500 \mathrm{~mL}$ of distilled water was transferred to the reactor and then the metal rod was locked on the mechanical stirrer. Lime was added and the reactor lid was immediately closed, the stirrer was then activated and the reaction temperature was monitored for 1 hour. The procedure is analogous to the reaction of lime with green liquor.

\section{- Activity 4 - Conducting filtration tests for the separation of lime sludge and white liquor (byproducts of the causticizing)}

After completing the causticizing reaction experiments, the resulting solutions were filtered in order to separate the lime sludge $\left(\mathrm{CaCO}_{3}\right)$ from the white liquor $\left(\mathrm{NaOH}\right.$ and $\left.\mathrm{Na}_{2} \mathrm{~S}\right)$ generated. The filtration utilized the Kitassato apparatus and Büchner funnel, and the filter medium used was supplied by a pulp mill in order to reproduce the solid-liquid separation in the laboratory. In this way, the filtrate volumes were determined (by measuring the volume retained in the kitassato after 
filtration), amount and solids content of the cake formed (by comparing the mass at the end of the filtration and after the cake was dried).

From the literature, it was possible to find another filtration system on a laboratory scale: The Leaf test. This is widely used to test important filtration characteristics as is simple to assemble and operate (Coulson \& Richardson, 2019). In this type of filtration, the filter coupled to the filter medium is immersed in a container that contains the aqueous suspension to be filtered and, by means of a vacuum, the solution and cake are separated. The tests that use inferior feeding are appropriate for simulating rotating drum and disc filters, since they do not depend only on gravity (Cardoso, 2018).

Figure 1 - Filtration scheme using the Leaf Test

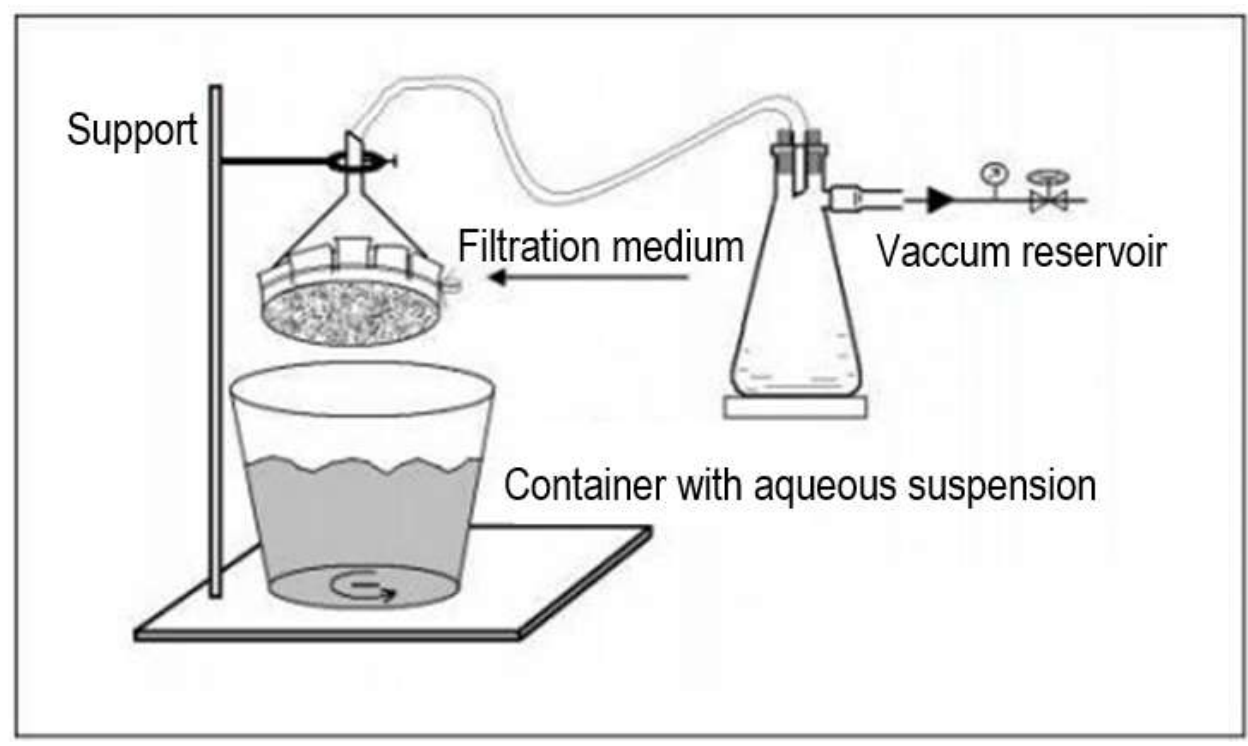

Source: Cardoso (2018).

The two filtration devices were then compared according to time and volume of filtrate, using the same solution of lime and water.

\section{Results and Discussion}

While monitoring the progress of the projects through periodic meetings, reading the reports and following the presentations, it was possible to monitor the students' attitudes, skills and competences, as the projects evolved. This section summarizes the results of the technical activities carried out in the projects and relates them to the attitudes, skills and competences worked on with the students. The data presented here respect the confidentiality terms signed and agreed to by the project partner companies for their protection.

\subsection{Activities developed in the projects: results of technical application}

- Activity 1 - Preparation of the thermal insulation of a batch chemical reactor

The thermal insulation of the reactor was divided into stages, explained in section 2.2, and these can be seen in Figure 2. 
Figure 2 - A) Coating the metallic reactor with rock wool; B) Covering with wool blanket; C) Plastic container with Styrofoam plate at the bottom; D) Installation of a Styrofoam cylinder on the sides of the container and setting with expansive foam; E) Fixing the reactor in the container; F) Reactor completed.

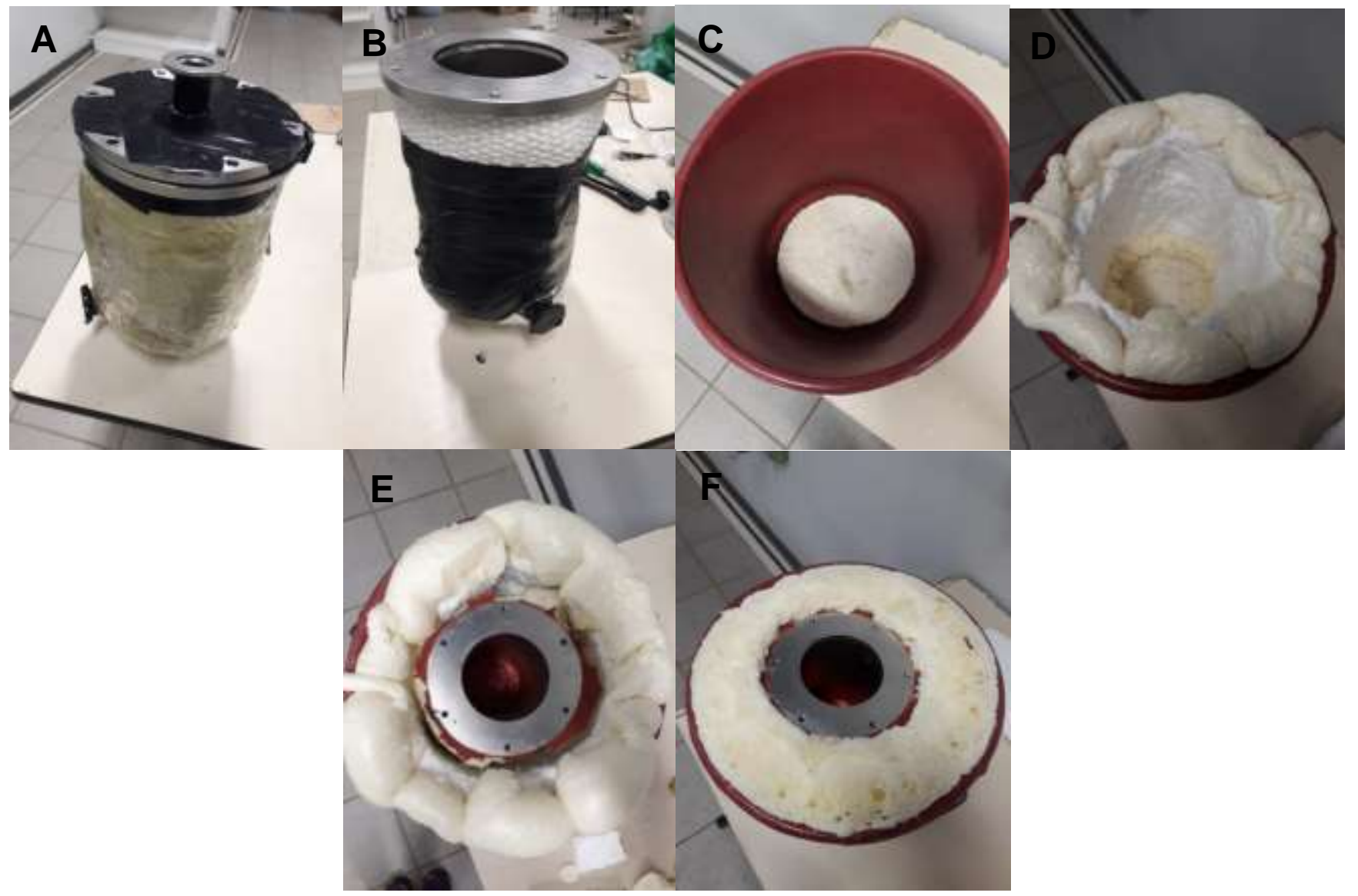

Source: Authors.

The reactor cover went through the same steps and coatings as the reactor so that only the space for the metal rod of the mechanical stirrer was left open. The result of the experimental setup can be seen in Figure 3. 
Figure 3 - Experimental Setup.

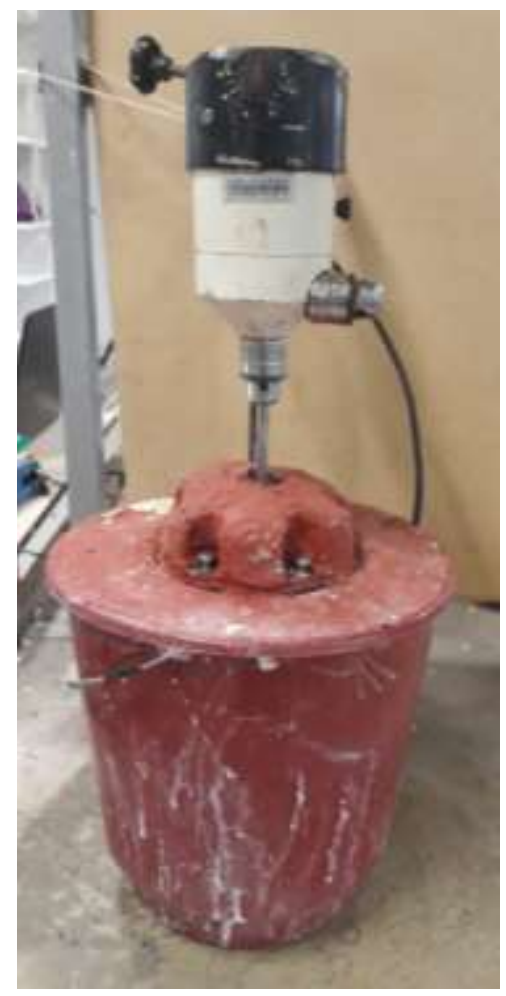

Source: Authors.

In order to quantify the heat loss of the reactor and, thus, the efficiency of thermal insulation, measurements of the temperature decay over time for water and clarified green liquor were performed. For this, $500 \mathrm{~mL}$ of heated distilled water was added to the reactor, which was kept closed for at least 1.5 hours to monitor the temperature drop. The same was done with heated green liquor and the temperature profile over time can be seen in Figure 4.

Figure 4 - Graph of the clarified green liquor and water temperature decay profile.

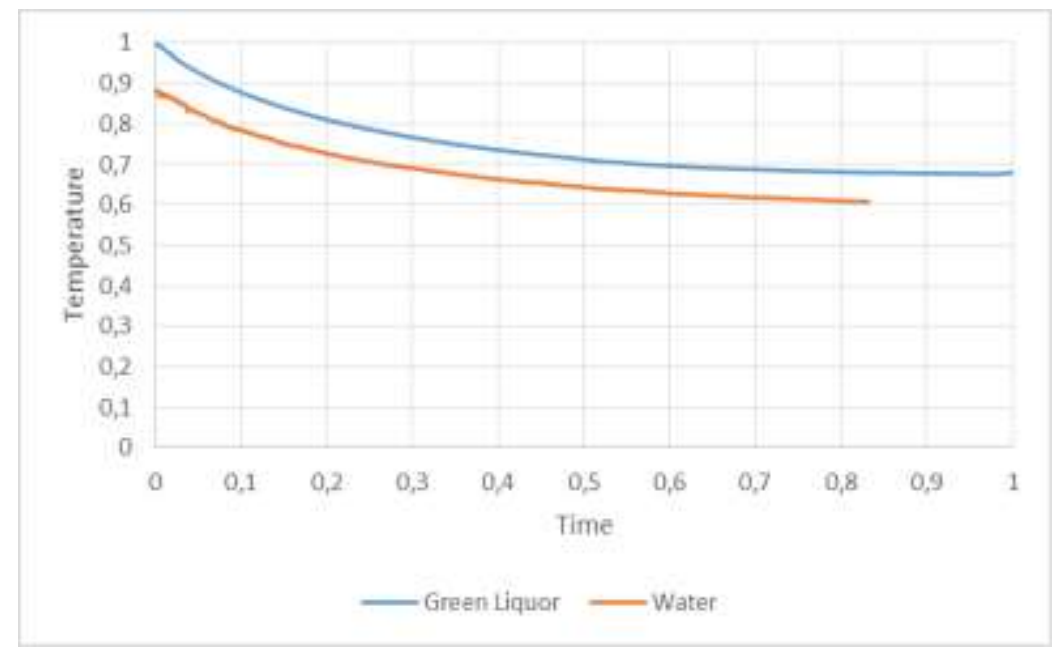

Source: Authors.

From these data, and matching the fundamental equations of calorimetry (Equation 1) and the global heat transfer coefficient (Equation 2) (Incropera, et al., 2008), it was possible to calculate the overall heat exchange coefficient of the reactor and also the specific heat of the clarified green liquor. 
$\dot{Q}=m c_{p} \Delta T$

$\dot{Q}=U A \Delta T_{\text {total }}$

Equating the equations (1) and (2):

$\dot{Q}=U A \Delta T_{\text {total }}=m c_{p} \Delta T$

$m c_{p} \frac{\partial T}{\partial t}=-U A\left(T-T_{\infty}\right)$

$\frac{\partial T}{\partial t}=-\frac{U A}{m c_{p}}\left(T-T_{\infty}\right)$

$\frac{\partial T}{\partial\left(T-T_{\infty}\right)}=-\frac{U A}{m c_{p}} \partial t$

Integrating, we obtain the equation:

$\int \frac{\partial T}{\partial\left(T-T_{\infty}\right)}=-\frac{U A}{m c_{p}} \int \partial t$

$\left.\ln \left(T-T_{\infty}\right)\right|_{0} ^{\infty}=-\left.\frac{U A}{m c_{p}} t\right|_{0} ^{\infty}$

$\ln \frac{\left(T-T_{\infty}\right)}{\left(T_{0}-T_{\infty}\right)}=-\frac{U A}{m c_{p}} t$

$\frac{\left(T-T_{\infty}\right)}{\left(T_{0}-T_{\infty}\right)}=e^{-\left(\frac{U A t}{m c_{p}}\right)}$

Through Equation 10 it was possible to find the global heat transfer coefficient $(\mathrm{U})$, since the heat exchange area (A), the total time (t), the mass used (m), and the heat are all known [specific $\left(\mathrm{c}_{\mathrm{p}}\right)$ of the water and the temperatures $(T, T \infty$ and $\left.\mathrm{T}_{0}\right)$ ]. Utilizing the data of the experiment with the green liquor and the obtained global heat transfer coefficient, it was possible to find the value of the specific heat of the clarified green liquor, applying it again in Equation 10.

A value of $0.0025 \mathrm{~W} / \mathrm{m}^{2} \mathrm{~K}$ was found for the global heat exchange coefficient $(\mathrm{U})$ and for the specific heat $\left(\mathrm{c}_{\mathrm{p}}\right)$ of the clarified green liquor 3.159 J / K.Kg. These values indicate that the assembled reactor is an efficient insulator, due to the low value found for $\mathrm{U}$.

- Activity 2 - Monitoring the reaction temperature over time (reactivity)

The reaction temperature was monitored by means of a temperature sensor (thermocouple) inserted in the reactor cover and connected by the yellow, black and red wires, shown at the bottom of Figure 5, the prototype platform of Arduino UNO. In this fashion, the temperature was measured autonomously and presented on a serial monitor every 2 seconds. 
Figure 5 - Arduino UNO assembly for temperature reading.

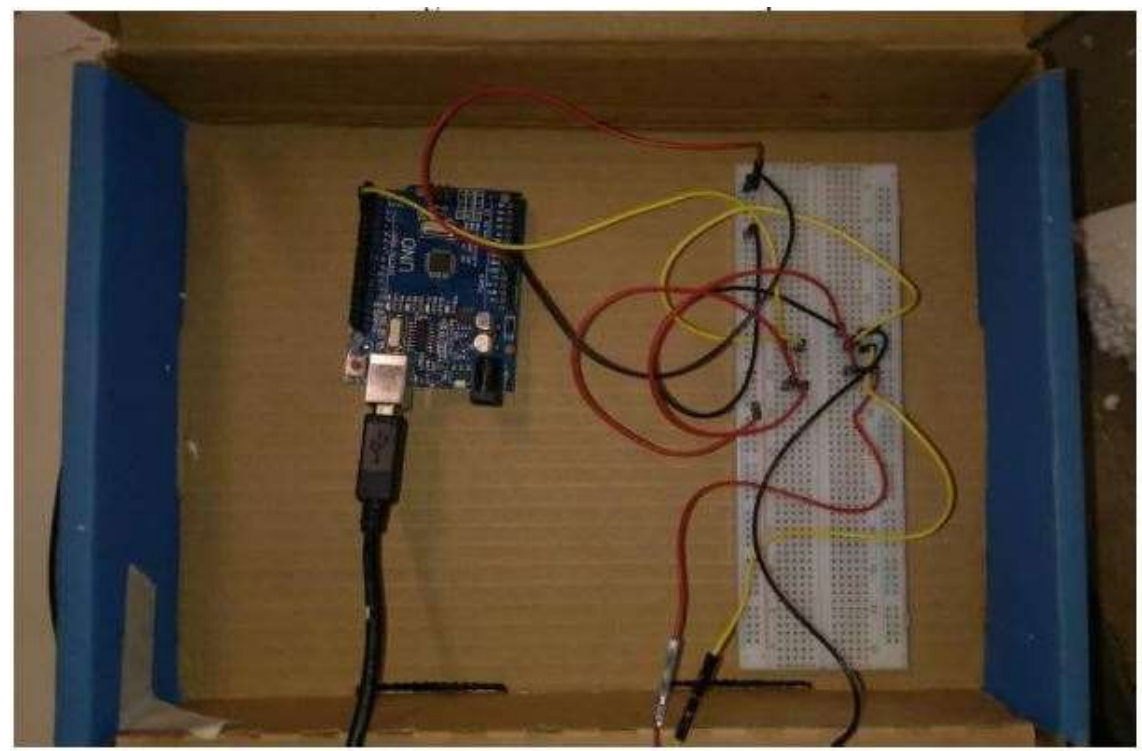

Source: Authors.

- Activity 3 - Carrying out the experimental tests between lime and water or green liquor

Figure 6 shows the temperature profile over time obtained from the causticizing that was carried out. One can see that by using the reactor coated with insulating materials it was possible to observe the temperature rise resulting from the heat release from the reaction. Due to this, the proposed reactor achieved the objective of containing the heat so that the reaction could be evaluated and in a similar way, it can be applied in other projects of the lime study group in the pulp mill. Additionally, the reactor was developed using low-cost materials, since the laboratory does not have the resources to acquire specific equipment for the causticizing reaction. Finally, the work provided knowledge, since the students sourced and evaluated the materials that would be suitable for the reactor objective, applying the knowledge they acquired in the Chemical Engineering course. As a result, the reactor was built with alternative materials and technically appropriate and applicable to the process.

Figure 6 - Temperature profile as a function of the causticizing time.

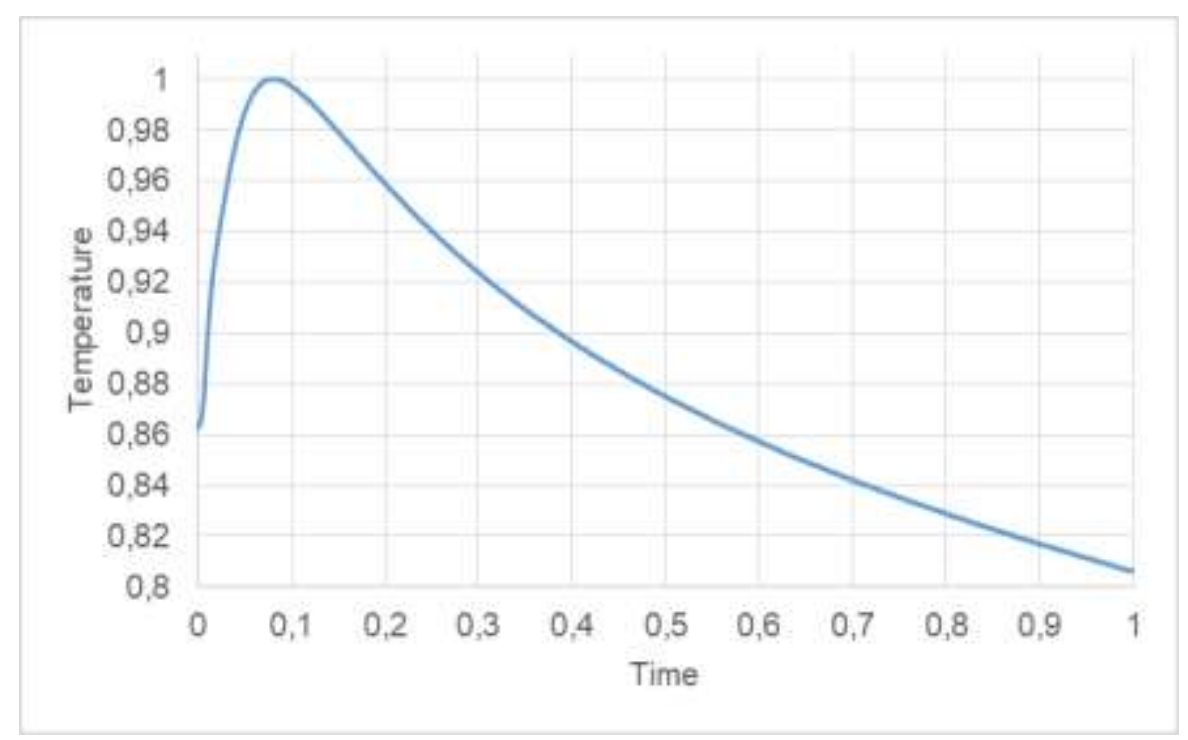

Source: Authors. 
- Activity 4 - Conducting filtration tests for the separation of lime sludge and white liquor (byproducts of the causticizing)

The prototype of the Leaf test filter printed in polymeric material (TRITAN HT) on the 3D printer available in the University's laboratory is shown in Figure 7. The advantages of 3D printing are many and diverse: manufacturing with high precision, production of complex shapes, flexibility, low material cost and application in several areas (Ngo, et al., 2018). In addition, it was possible to perform various tests and make adjustments until reaching the format and size shown below, which proved viable for the application of filtrating lime sludge in the laboratory, since it proved to be resistant and with adequate solid-liquid separation capacity.

Figure 7 - Prototype of the P02 leaf test filter.
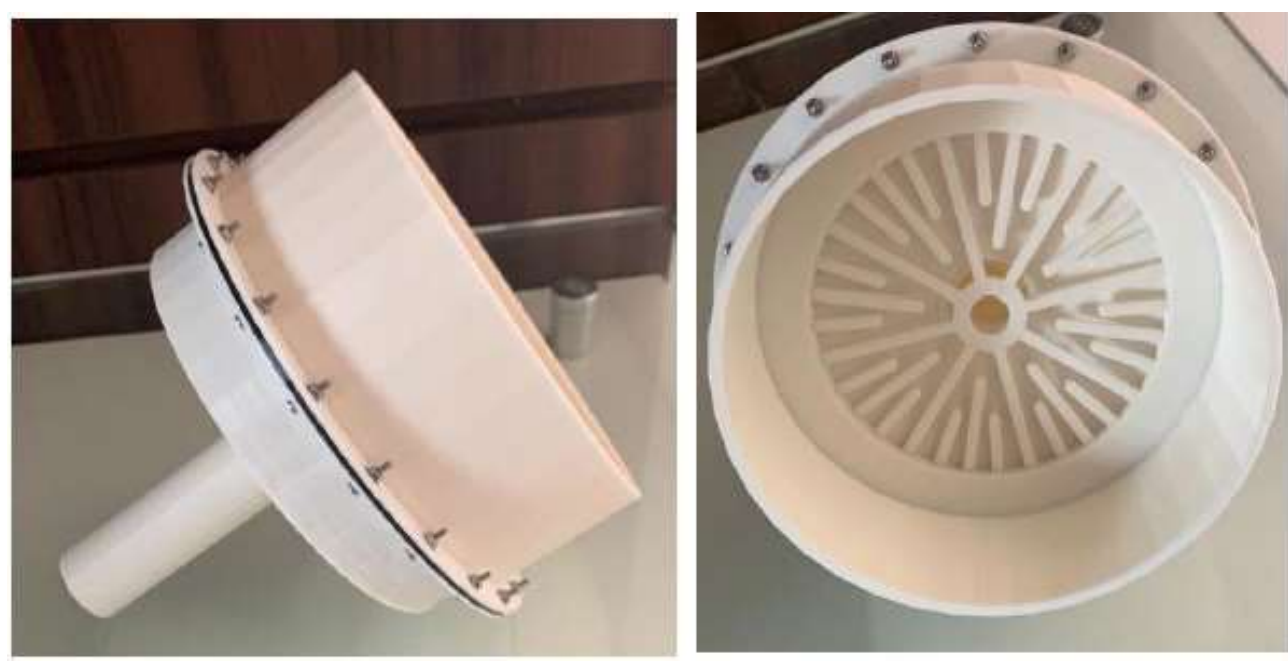

Source: Authors.

"Analyzing the two filtration processes carried out, it can be seen that the leaf test showed a shorter filtration time when compared to the test with the Büchner funnel. This is associated with the fact that immersion filtration requires less energy, since the filter operates drowned in a saline solution, whose system has a pressure lower than the atmospheric pressure of the test with the Büchner funnel. As a result, the lesser energy requirement implies that the process can be completed in less time. Thus, even though the tests were performed in different ways, the analysis of the time variable allows us to conclude that the Leaf test is more recommended for the filtration of the lime solution, since this method had a filtration time less than 21.25 $\%$ when compared to the Büchner funnel.” (França, et al., 2020)

\subsection{Matrix of general competences of the chemical engineer: integration of the PBL into the LOP class material}

The table below outlines the knowledge, skills and attitudes that each group of students developed or enhanced through their work based on the challenges faced, while considering relevant cost, feasibility, time and the objective analyzes to be achieved. The decisions made throughout the project were the results of both individual and group research performed by the students, in addition to meetings for discussion with advisors and industry experts, in person or remotely, in order to evaluate the best path to be followed. The program demonstrated that the laboratory experience combined with weekly meetings made it possible to assess the negative aspects of the work and, subsequently, improvements were proposed. The contribution of each member with their individual experiences and the exchange that was made possible through the knowledge network that was formed also proved to be of great value. 
The matrix of general Chemical Engineering competencies by project developed in the LOP subject is presented below. The objectives of the projects were identified and the potential mobilization of each competence highlighted in the results were presented in the reports produced by the students and analyzed.

Table 2 - Matrix of general engineering skills applicable in the development of project methodology.

\begin{tabular}{|c|c|}
\hline \multicolumn{2}{|r|}{ Project A } \\
\hline $\begin{array}{l}\text { Holistic and humanistic } \\
\text { vision }\end{array}$ & $\begin{array}{l}\text { Necessity or problem situation: Exploratory study to clarify how the silica }\left(\mathrm{SiO}_{2}\right) \text { content present in lime and } \\
\text { granulometry influence the reactivity (accompanying the increase in temperature as a function of time) and the } \\
\text { filtration of lime sludge (separation of white liquor and lime mud). } \\
\text { Motivating factor: Lack of knowledge on the part of the industry of how the granulometry and chemical } \\
\text { composition of lime (contaminants) influence the lime recovery step of the Kraft pulp production process. }\end{array}$ \\
\hline $\begin{array}{l}\text { Technical } \\
\text { degree/training }\end{array}$ & $\begin{array}{l}\text { Characterization of the analyzed limes (comparison of chemical composition in relation to silica content). } \\
\text { Reactor coating to minimize thermal loss and evaluate the performance of exothermic reactions (quantify the } \\
\text { reaction temperature variation). Reproduction of the causticizing in the laboratory at the initial ambient } \\
\text { temperature, and evaluation of the heat loss of the reactor used. Quantification of the silica content present in the } \\
\text { white liquor. Lime sludge filtration using the Buchner and Kitassato Funnel set. }\end{array}$ \\
\hline Digital technologies & $\begin{array}{l}\text { Use of the WhatsApp messaging platform to monitor the progress of the project, questions, suggestions and } \\
\text { scheduling of meetings. }\end{array}$ \\
\hline $\begin{array}{l}\text { Multidisciplinarity and } \\
\text { interdisciplinarity } \\
\text { approach }\end{array}$ & Summation of engineering knowledge (Unit operations and heat transfer). \\
\hline $\begin{array}{l}\text { Engineering } \\
\text { troubleshooting }\end{array}$ & $\begin{array}{l}\text { The lime samples selected for this work came from different calcination processes and different deposits, } \\
\text { resulting in different byproducts that directly influence reactivity. During the causticizing, the analyzed limes } \\
\text { had a relatively small increase in temperature (around } 10^{\circ} \mathrm{C} \text { ) due to the reaction being conducted at the initial } \\
\text { ambient temperature. It was observed that the limes of smaller granulometry had the highest reactivity. Minimal } \\
\text { thermal loss of the reactor }\left(1.4^{\circ} \mathrm{C} \text { in } 30 \text { minutes), a satisfactory amount for evaluating the reactivity without }\right. \\
\text { compromising the data due to heat loss to the environment. The silica content in the liquor was quantified and } \\
\text { about } 15 \text { to } 25 \% \text { that was present in the lime was dissolved in the white liquor. During filtration, gel formation } \\
\text { was discovered in the filtering tissue and the analysis confirmed the presence of silicon oxide, revealing that the } \\
\text { silica gel is formed on the filtering tissues making it difficult to filter the lime sludge. It was also observed that } \\
\text { the samples that had a higher silica content had longer filtration times. }\end{array}$ \\
\hline Evaluative capacity & $\begin{array}{l}\text { Suggestions for future work: Automation of temperature measurement in order to reduce operational errors and } \\
\text { increase the amount of data collected. Reproduction of the causticizing at the maximum temperature (about } 100^{\circ} \\
\text { C), close to what occurs in the industry, to more efficiently evaluate the influence of the particle size and } \\
\text { composition of the lime in this reaction. More detailed studies related to silica gel formation. }\end{array}$ \\
\hline \multicolumn{2}{|r|}{ Project B } \\
\hline $\begin{array}{l}\text { Holistic and humanistic } \\
\text { vision }\end{array}$ & $\begin{array}{l}\text { Necessity or problem situation: Assess how the effects of lime contaminants (silicon, magnesium and aluminum } \\
\text { oxides) influence the filtration of lime sludge. Motivating factor: These characteristics are not found in the } \\
\text { literature and the industry has also failed to clarify how these factors interfere with reactions. Interest in the study } \\
\text { of other contaminants was opened in addition to silica. }\end{array}$ \\
\hline $\begin{array}{l}\text { Technical } \\
\text { degree/training }\end{array}$ & $\begin{array}{l}\text { Use of synthetic and industrial limes. Synthetic limes }(\mathrm{CaO}) \text { have enabled the manipulation of the content of } \\
\text { contaminants to obtain a larger range, which is not possible with industrial lime, since this material is derived } \\
\text { from limestone that has a pre-defined chemical composition. The industrial samples selected, as in project A, } \\
\text { came from different deposits to evaluate chemical compositions. The granulometry was kept constant }\end{array}$ \\
\hline
\end{tabular}




\begin{tabular}{|c|c|}
\hline & $\begin{array}{l}\text { (micropulverized) to control for this factor and evaluate only the composition. Chemical characterization of } \\
\text { limes for the quantification of contaminants. Use of an automated temperature measurement system coupled to } \\
\text { the reactor. Test of the thermal loss of the reactor using the liquor at } 60^{\circ} \mathrm{C} \text {. Note that the thermal loss increased } \\
\text { significantly, compromising the results. Conducting experiments to reproduce reactions at initial room } \\
\text { temperature to minimize the influence of heat loss on the environment. Increased reaction time (Project A } \\
\text { monitored the reaction temperature for } 30 \text { minutes) to } 90 \text { minutes since it was estimated that } 30 \text { minutes was } \\
\text { insufficient. Lime sludge filtration performed again using the Buchner and Kitassato funnel since it is the most } \\
\text { accessible and commonly applied device for laboratory filtration tests. Analysis of the results (solids content in } \\
\text { mud and contaminant content in lime) using a statistical tool (design of experiments) to measure the effect of } \\
\text { each contaminant, as well as if there are combined effects on filtration. }\end{array}$ \\
\hline Digital technologies & $\begin{array}{l}\text { Use of the Arduino Uno prototyping platform to monitor the reaction temperature automatically and in real time. } \\
\text { Use of the WhatsApp messaging platform to monitor the progress of the project, questions, suggestions and } \\
\text { scheduling of meetings. Use of Minitab statistical software to present a model that represents the evaluated } \\
\text { parameters. }\end{array}$ \\
\hline $\begin{array}{l}\text { Multidisciplinarity and } \\
\text { interdisciplinarity } \\
\text { approach }\end{array}$ & Summation of engineering knowledge (Statistics, unit operations, kinetics and heat transfer). \\
\hline $\begin{array}{l}\text { Engineering } \\
\text { troubleshooting }\end{array}$ & $\begin{array}{l}\text { Similarity in the behavior trend was observed between synthetic and industrial limes. It was not possible to } \\
\text { standardize the initial temperature and agitation of the mechanical stirrer and these factors were associated with } \\
\text { differences in the temperature profiles (temperature variation with time) of the replicates. A significant loss of } \\
\text { heat to the environment was observed during the reaction, a factor that may have compromised the results found. } \\
\text { It was observed that the content of solids in the lime mud decreases as the content of the contaminants increases. } \\
\text { The trend lines that correlated the solids content and the level of contaminants present in the lime showed high } \\
\text { standard deviation. This was attributed to the imprecision of the filtration method, suggesting the development of } \\
\text { filtration equipment that could better represent what occurs in real world conditions. } \\
\text { In the statistical analysis of the results, when applying the method of design of experiments, it was possible to } \\
\text { conclude that the model found has the necessary requirements for its validation. Among the contaminants studied } \\
\text { the one that most impacted the filtration of lime sludge was aluminum oxide, followed by silicon oxide and } \\
\text { magnesium oxide. Regarding the combined effects of these contaminants, it was found that aluminum oxide and } \\
\text { magnesium oxide interact with each other, and the relationship between the solids content and each of these } \\
\text { contaminants are mutually dependent. }\end{array}$ \\
\hline Evaluative capacity & $\begin{array}{l}\text { Suggestions for future studies: Improving the thermal coating of the reactor. Standardization of initial } \\
\text { temperature and agitation. Development of a more accurate filtration device. Evaluation of other filtration } \\
\text { parameters in addition to the solids content in the lime mud, such as filtration time, filtration rate, and pie } \\
\text { properties, for example. Relating the size and distribution of white liquor particles to the filtration and solids } \\
\text { content of the sludge and lime contaminants. Further investigation of the combined effects. Analysis of the } \\
\text { chemical composition of lime mud. }\end{array}$ \\
\hline \multicolumn{2}{|r|}{ Project $\mathrm{C}$} \\
\hline $\begin{array}{l}\text { Holistic and humanistic } \\
\text { vision }\end{array}$ & $\begin{array}{l}\text { Necessity or problem situation: Evaluate how the granulometry and chemical composition factors of the lime } \\
\text { influence the reactivity of its slaking and causticizing reactions and the sludge filtration parameters (filtration } \\
\text { time and moisture content of the cake). Motivating factor: These characteristics are not found in the literature and } \\
\text { the industry has also failed to clarify how these factors interfere with reactions. }\end{array}$ \\
\hline $\begin{array}{l}\text { Technical } \\
\text { degree/training }\end{array}$ & $\begin{array}{l}\text { Lime samples were taken from the same deposit on different days. The granulometric ranges selected were } 0 \text { to } 3 \\
\mathrm{~mm}, 3 \text { to } 19 \mathrm{~mm} \text { and } 19 \text { to } 40 \mathrm{~mm} \text {. Chemical characterization of limes for the quantification of contaminants. } \\
\text { Improvement of the thermal insulation of the reactor with a thick layer of glass wool and a Styrofoam container }\end{array}$ \\
\hline
\end{tabular}




\begin{tabular}{|c|c|}
\hline & $\begin{array}{l}\text { (insulating materials). The number of experiments was increased in relation to project B and the chemical } \\
\text { composition of the limes was evaluated. The initial temperature was ambient for the slaking reactions (lime and } \\
\text { water) and a temperature of } 75^{\circ} \mathrm{C} \text { was determined for the causticizing reactions (lime and green liquor). It was } \\
\text { decided that causticizing would occur at a high temperature to approximate what is practiced in the industry and } \\
\text { increase the efficiency of the reaction, since the last two projects (A and B) found low efficiency. Use of the } \\
\text { same automated system for temperature measurement. Filtration also used the Buchner and Kitassato funnel } \\
\text { system, but a container was added before the funnel to stir the solution and pour the homogeneous solution. A } \\
\text { valve was inserted into the container so that the solution was poured slowly. Evaluation of parameters related to } \\
\text { filtration (filtration time and moisture content of the cake). Use of a statistical tool (design of experiments) to } \\
\text { measure and validate how each factor influences the response (lime reactivity). }\end{array}$ \\
\hline Digital technologies & $\begin{array}{l}\text { Use of the Arduino Uno prototyping platform to monitor the reaction temperature automatically and in real time. } \\
\text { Use of the WhatsApp messaging platform to monitor the progress of the project, questions, suggestions and } \\
\text { scheduling of meetings. Use of Minitab statistical software to present a model that represents the evaluated } \\
\text { parameters. }\end{array}$ \\
\hline $\begin{array}{l}\text { Multidisciplinarity and } \\
\text { interdisciplinarity } \\
\text { approach }\end{array}$ & Summation of engineering knowledge (Statistics, unit operations, kinetics and heat transfer). \\
\hline $\begin{array}{l}\text { Engineering } \\
\text { troubleshooting }\end{array}$ & $\begin{array}{l}\text { It was found that the lowest level of granulometry resulted in the smallest temperature variation, these factors } \\
\text { being directly proportional. By Fisher's comparison method, it was found that the limes that were selected in the } \\
\text { granulometric ranges of } 3 \text { to } 19 \text { and from } 19 \text { to } 40 \mathrm{~mm} \text { belonged to the same group and that this group was a } \\
\text { different one from the one that limes from } 0 \text { to } 3 \mathrm{~mm} \text { belonged to. Therefore, it was to be expected that these } \\
\text { limes would show different results and that the lime granulometry would influence the reactivity. The chemical } \\
\text { composition was found to have no influence on reactivities, since the limes' compositions were similar. The } \\
\text { experiments showed excellent reliability, because the standard deviations obtained were low and the errors less } \\
\text { than } 10 \% \text {. It was found that the granulometry does not influence the filtration time and the moisture content of } \\
\text { the cake. The same result was observed when the chemical composition was analyzed. High standard deviation } \\
\text { values were observed, indicating that these findings were not statistically reliable. Proposal for a new filter from } \\
\text { the literature that can replace the problem of the current device (Buchner and Kitassato funnel). It was not } \\
\text { possible to carry out the analysis of the size and distribution of particles in the lime mud, due to technical } \\
\text { problems in the company that performs the analysis. }\end{array}$ \\
\hline Evaluative capacity & $\begin{array}{l}\text { Suggestions for future studies: Add an automated measurement of the filtrate flow, increasing the filtration } \\
\text { analysis variables. Construction of the filtration system proposed in this project (Leaf test) supported by } \\
\text { electronic sensors. Analyzing the particle size distribution formed in the white liquor. Also, analyzing the limes } \\
\text { recovered in the causticizing cycle of the Kraft process, in order to clarify the influence of the accumulation of } \\
\text { contaminants. }\end{array}$ \\
\hline \multicolumn{2}{|r|}{ Project D } \\
\hline $\begin{array}{l}\text { Holistic and humanistic } \\
\text { vision }\end{array}$ & $\begin{array}{l}\text { Necessity or problem situation: Develop a filtration system that could reproduce the filtration of lime mud in a } \\
\text { similar fashion to what occurs in the industry on a laboratory scale. Comparison with the Buchner and Kitassato } \\
\text { Funnel filtration device. Additional evaluation of the filtrate volume, filtration rate, percentage of solids and } \\
\text { moisture in the cake operating parameters. Motivating factor: The filter commonly used for this purpose } \\
\text { (Buchner funnel and Kitassato) has already been tested and has no reproducibility or statistical reliability. There } \\
\text { is no other equipment on the market that can be purchased to meet this need. }\end{array}$ \\
\hline $\begin{array}{l}\text { Technical } \\
\text { degree/training }\end{array}$ & $\begin{array}{l}\text { Conventional filters depend, among other factors, upon the intensity of the solid-liquid separation. A bench scale } \\
\text { filter model that uses the lower feed was found in the literature. It was possible to evaluate the operation of rotary } \\
\text { and disc drum filters, equipment found in the pulp mill in the separation of lime sludge and white liquor. This }\end{array}$ \\
\hline
\end{tabular}




\begin{tabular}{|c|c|}
\hline & $\begin{array}{l}\text { filter model is referred to as a Leaf test, and was originally designed to be made of metal. It was produced on a } \\
\text { 3D printer and the materials chosen were ABS (Acrylonitrile butadiene styrene) and TRITAN HT. These } \\
\text { materials are inexpensive, strong, flexible and resistant, essential characteristics for a filter. Technical drawings } \\
\text { in } 2 \text { and 3D were made using the Autocad software package. The evaluation of parameters related to filtration } \\
\text { (filtrate volume, filtration rate, percentage of solids and cake moisture) using the Leaf test prototype and the } \\
\text { previous filtration system (Buchner funnel and Kitassato) was performed for comparison purposes. The solution } \\
\text { prepared for the filtration was lime and water, and used for both filtration systems. }\end{array}$ \\
\hline Digital technologies & $\begin{array}{l}\text { Meetings held by videoconferencing platforms (Google Meet and Hangouts). Use of the WhatsApp messaging } \\
\text { platform to monitor the progress of the project, questions, suggestions and scheduling of meetings. Final } \\
\text { presentation of the project to the evaluation panel through the Microsoft Teams platform (chosen as the official } \\
\text { platform by the institution), facilitating access by many people in the conference room and recording of the } \\
\text { evaluation seminar. Use of technical drawing software (Autocad 2D and 3D). }\end{array}$ \\
\hline $\begin{array}{l}\text { Multidisciplinarity and } \\
\text { interdisciplinarity } \\
\text { approach }\end{array}$ & Summation of engineering knowledge (unit operations, modeling and technical drawing). \\
\hline $\begin{array}{l}\text { Engineering } \\
\text { troubleshooting }\end{array}$ & $\begin{array}{l}\text { The parts of the first prototype (called P01) were printed separately to be joined together, Initially, the printed } \\
\text { surfaces were very rough which prevented the original joint assembly of the parts. After the first filtration, P01 } \\
\text { broke due to the fragility of the junction two parts of the filter (called solid and tube) that were joined using glue. } \\
\text { The first comparison showed that filtration using the prototype was carried out in less time and the cake had } \\
\text { lower moisture content, indicating an improvement over the other system. In the second prototype, flanges were } \\
\text { added for attaching screws to achieve a better fit between the parts. The junction that was previously made using } \\
\text { glue has been eliminated by resizing the pieces so that the tube fit inside the solid. In Additionally, the } \\
\text { operational parameters (density and filling pattern, distance between part and support, height of the layers, } \\
\text { printing speed and cooling mode) were changed in order to reduce the roughness and fragility of the filter. A new } \\
\text { prototype was printed and named P02. Filtration was performed using P02, which proved to be more efficient } \\
\text { compared to P01, and consequently to the Buchner and Kitassato funnel. At the end of the filtration, the P02 } \\
\text { remained intact, indicating an improvement in the filter. }\end{array}$ \\
\hline Evaluative capacity & $\begin{array}{l}\text { Suggestions for future work: Develop a sensing system (flow measurement). Adaptation of the fixing mechanism } \\
\text { of the filter medium to avoid retaining the cake at the ends. Usage of transparent materials in the filters and the } \\
\text { filtrate tank for dynamic filtration monitoring. }\end{array}$ \\
\hline
\end{tabular}

Source: Authors.

The analysis of the general engineering skills matrix facilitates in the clarification of the problem situation that the students observed and what they gained from the experience of the industry professionals considering their necessities and taking into account a broader evaluation of economic, social, environmental and cultural aspects. Each group strove to understand the physical and chemical phenomena involved in the reactivity and the results of the lime and the filtration of the lime sludge and, for that, they proposed a methodology based on the principles learned during their academic course instruction. In this fashion, students were able to apply the knowledge acquired in various subjects studied and to use mathematical, statistical and computational tools to validate and analyze the results found. Digital technologies were included in the projects to assist and automate measurements, reducing experimental errors on the part of operators and making the interaction between industry professionals, students and teachers increasingly dynamic. Finally, the students were able to discuss the results, assessing the context, devising viable and interesting solutions from an industrial point of view.

With each project it was possible to identify the construction of collective knowledge and its evolution compared to the previous ones, since many issues were confronted during development (for example, the lack of appropriate equipment, 
reactions and filtration) and subsequently solutions were found and presented. The students' capacity for evaluation and creativity was developed by suggesting solutions to the next groups based on their own experiences. Through this process the students showed themselves to be autonomous and the protagonists of their projects, since they outlined the objectives of each project, proposed the methodology to be used and confronted the challenges encountered, building or adapting the equipment they needed and searching in other laboratories for the tools needed.

\section{Conclusion}

This report portrays how the Project-Based Learning methodology was applied in the LOP course based upon the students' choice of the theme of work and the related group of teachers in orientation, and by the students' autonomy in conducting each project, defining the goals to be achieved and the methodology applied. And, additionally, due to the students' ability to understand the problem situations presented by industry professionals and the systemic and broad assessment of the issues to be addressed by them in their projects. These projects stimulated the students to seek solutions for the lack of resources for the acquisition of equipment and supplies, building and/or adapting the tools that were available. They were able to learn from each task performed and developed their creativity by proposing practical and applicable solutions to the next groups based on the experiences they had. They also exercised their ability to think critically when questioning and analyzing the results found, applying the knowledge learned during the Chemical Engineering course and collectively building the reports that were examined in the general engineering skills matrix. The interaction between students, teachers and industry professionals proved to be essential in this process, since it allowed for a better and deeper analysis of the theme and the optimal use of working time, based on the sharing of knowledge and the experience of each participant. Digital communication technologies also aided in the exchange of information in a dynamic fashion and led to the debate of issues raised in a network format. In this way, the PBL methodology contributed to the development of all of the competencies including "holistic and humanistic vision, degree \& technical training, incorporation of digital technologies, interdisciplinary and multidisciplinary approach, solution of engineering problems and evaluative capacity" outlined in the National Curriculum Guidelines and for the construction of proactive and dynamic curricula by these students.

\section{References}

Belisário, A. B., Faria, D. G., Chaves, D. H. S., Almeida, G. M., \& Cardoso, M. (2020). Reports of Experience of Insertion of Digital Technologies in the Teaching of Engineering. Higher Education Teaching Journal. 10, 1-18. doi:10.35699/2237-5864.2020.15139

DCN - Brazil. (2019). Ministry of Education. Higher Education Secretariat. Curricular Guidelines for undergraduate engineering courses. Resolution CNE/CES 2, of April 24, 2019. Retrieved October 5, 2020, from http://portal.mec.gov.br/index.php?option=com_docman\&view=download\&alias=112681rces002-19\&category_slug=abril-2019-pdf\&Itemid=30192

Cambi, F. (1999). History of Pedagogy. UNESP.

Camilo, J. P. G., \& Araújo, L. G. (2019). Preliminary analysis of the filterability tests of white liquor from different limes in the pulp mill. Chemical Engineering Final Project - Chemical Engineering Department, Federal University of Minas Gerais, Belo Horizonte.

Cardoso, M. P. (2018). Prototype of a portable filter to perform the Leaf-test by lower power. Monograph (Bachelor of Mining Engineering) - Federal Center for Technological Education of Minas Gerais, Araxá. http://www.eng-minas.araxa.cefetmg.br/wp-content/uploads/sites/170/2018/12/Mateus-de-PaivaCardoso-min.pdf

Charle, C., \& Verger, J. (2007). History of universities. What do I know. University presses of France.

Castells, M. (2009). Communication Power. Oxford University Press.

Coulson, J. M., \& Richardson, J. F. (2019). Coulson and Richardson's Chemical Engineering. Amsterdam: Butterworth-Heinemann.

França, B. T., Fajardo, G. L., Ferreira, L. M., Sousa, M. A., \& Barbosa, V. M. M. (2020). Prototyping and performance evaluation of a Leaf test filter. Chemical Engineering Final Project - Chemical Engineering Department, Federal University of Minas Gerais, Belo Horizonte.

Gerhardt, T. E., \& Silveira, D. T. (2009). Research methods. Coordinated by the Open University of Brazil - UAB / UFRGS and by the Technological Undergraduate Course - Planning and Management for Rural Development at SEAD / UFRGS.: UFRGS. 
Research, Society and Development, v. 10, n. 7, e40310715545, 2021

(CC BY 4.0) | ISSN 2525-3409 | DOI: http://dx.doi.org/10.33448/rsd-v10i7.15545

Gómes, A. I. P. (2011). Skills or practical thinking? The construction of meanings of representation and action, in: Sacristán, J. G., Gómez, A. I. P., Rodríguez, J. B. M., Santomé, J. T., Rasco, F. A., Méndez, J. M. A. Educating by competences: what's new? Artmed.

Han, B. (2017). In the Swarm: Digital Prospects. The MIT Press.

Incropera, F. P., Dewitt, D. P., Bergman, T. L., \& Lavine, A. S. (2008). Fundamentals of heat and mass transfer. LTC.

Jaeger, W. P. (1986). The ideal of Greek Culture. Oxford University Press.

Júnior, G M. V., Assunção, M. C., Fiuza, M. P. M., \& Silva, P. F. F. (2018). Influence of granulometry and silica content of quicklime in the Kraft pulp production process. Chemical Engineering Final Project - Chemical Engineering Department, Federal University of Minas Gerais, Belo Horizonte.

Markham, T., Larmer, J., \& Ravitz, J. (2003). Project Based Learning Handbook: A Guide to Standards-Focused Project Based Learning for Middle and High School Teachers. United States: Buck Institute for Education.

Marrou, H. (1981). History of education in Antiquity. Points.

Modelski, D., Giraffa, L. M. M., \& Casartelli, A. O. (2019). Digital Technologies, teacher training and teaching practices. Education and Research.. 45, 1-17. doi:10.1590/S1678-4634201945180201

Mosé, V. (2013). The School and Contemporary Challenges. Brazilian Civilization.

Ngo, T. D., Kashani, A., Imbalzano, G., Nguyen, K. T. Q., \& Hui, D. (2018). Additive manufacturing (3D printing): A review of materials, methods, applications and challenges. Composites Part B: Engineering. 143, 172-196. doi:10.1016/j.compositesb.2018.02.012

Perry, R. H., \& Green, D. W. (1999). Perry's chemical engineers' handbook. United States: The McGraw-Hill.

Rettore, C. C., Souza, G. B. P., Faria, M. I. C., \& Anunciação, V. C. (2019). Analysis of the causticizing process from different samples of limes. Chemical Engineering Final Project - Chemical Engineering Department, Federal University of Minas Gerais, Belo Horizonte.

Ribeiro, L. R. C., \& Mizukami, M. G. N. (2005). Student assessment of a problem-based learning experimente in civil engineering education. Journal of Professional Issues in Engineering Education and Practice. 131, 13-18. doi:10.1061/(ASCE)1052-3928(2005)131:1(13)

Sacristán, J. G. (2017). O Curriculum: a reflection on the practice. Morata. 